DOE/NASA CR-150841

\title{
LARGO HOT WATER SYSTEM THERMAL PERFORMANCE TEST REPORT
}

Prepared by

Wyle Laboratories

Solar Energy Systems Division

Huntsville, Alabama 35805

Under subcontract with IBM, Federal Systems Division, Huntsville, AL

Contract NAS8-32036

National Aeronautics and Space Administration

George C. Marshall Space Flight Center, Alabama 35812

For the U.S. Department of Energy
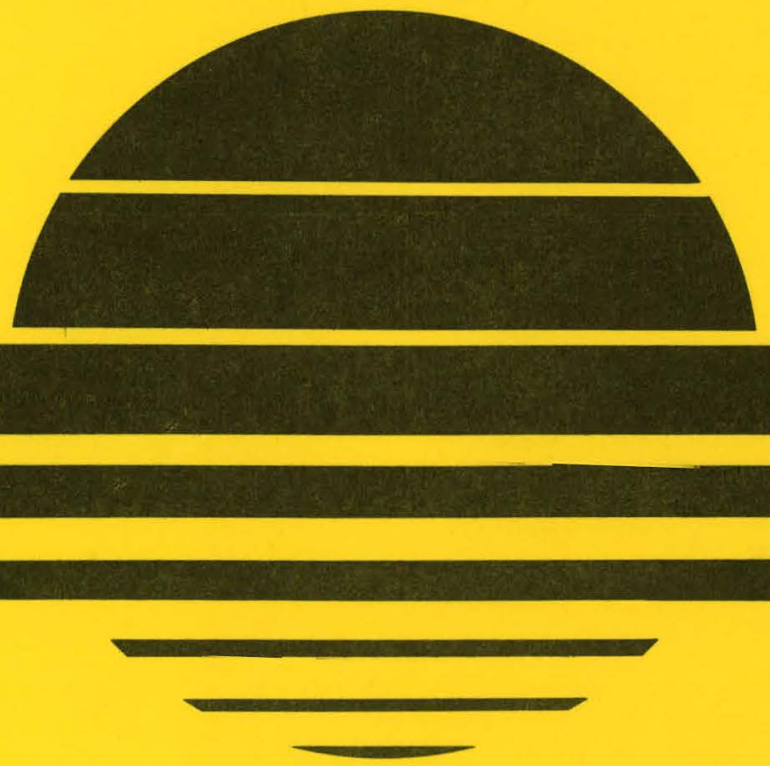

MASTER

\section{U.S. Department of Energy}

DLSTRIBUTION OF THIS DOCUMENT IS UNLIMITED 


\section{DISCLAIMER}

This report was prepared as an account of work sponsored by an agency of the United States Government. Neither the United States Government nor any agency Thereof, nor any of their employees, makes any warranty, express or implied, or assumes any legal liability or responsibility for the accuracy, completeness, or usefulness of any information, apparatus, product, or process disclosed, or represents that its use would not infringe privately owned rights. Reference herein to any specific commercial product, process, or service by trade name, trademark, manufacturer, or otherwise does not necessarily constitute or imply its endorsement, recommendation, or favoring by the United States Government or any agency thereof. The views and opinions of authors expressed herein do not necessarily state or reflect those of the United States Government or any agency thereof. 


\section{DISCLAIMER}

Portions of this document may be illegible in electronic image products. Images are produced from the best available original document. 
NOTICE

Th1s report was prepared to document work sponsored by the Unfted States Government. Nefther the Unfted States nor 1ts agents the United States Department of Energy, the United States Nat1onal Aeronaut1cs and Space Adminfstration, nor any federal employees, nor any of their contractors, subcontractors or the1r employees, make any warranty, express or 1mp11ed, or assume any legal 11ability or responsibllity for the accuracy, completeness, or usefulness of any information, apparatus, product or process disclosed, or represent that 1ts use would not infringe privately owned rights. 


\begin{tabular}{|c|c|}
\hline $\begin{array}{l}\text { 1. REPORT NO. } \\
\text { DOE/NASA CR-150841 }\end{array}$ & 3. RECIPIENT'S CATALOG NO. \\
\hline \multirow{2}{*}{ LARGO Hot Water System Thermal Performance Test Report } & $\begin{array}{l}\text { 5. REPORT DATE } \\
\text { NOVEmber } 1978\end{array}$ \\
\hline & 6. PERFORMING ORGANIZATION CCIDE \\
\hline 7. AUTHOR(S) & 8. PERFORMING ORGANIZATION REPOR' \\
\hline \multirow{3}{*}{$\begin{array}{l}\text { 9. PERFORMING ORGANIZATION NAME AND ADDRESS } \\
\text { Wyle Laboratories } \\
\text { Solar Energy Systems Division } 95^{\circ} 8^{34^{9}} \\
\text { Huntsville, Alabama } 35805\end{array}$} & 10. WORK UNIT NO. \\
\hline & $\begin{array}{l}\text { 11. CONTRACT OR GRANT NO. } \\
\text { NAS8-32036 }\end{array}$ \\
\hline & 13. TYPE OF REPORI \& PERIOD COVERED \\
\hline \multirow{2}{*}{$\begin{array}{l}\text { 12. SPONSORING AGENCY NAME AND ADORESS } \\
\text { National Aeronautics and Space Administration } \\
\text { Washington, D. C. } 20546\end{array}$} & Contractor Report \\
\hline & 14. SPONSORING AGENCY CODE \\
\hline \multicolumn{2}{|l|}{ 15. SUPPLEMENTARY NOTES } \\
\hline
\end{tabular}

16. ABSTRACT

This report presents the thermal performance tests and results on the LARGO Solar Hot Water System under natural environmental conditions. Some objectives of these evaluations are to determine the amount of energy collected,the amount of energy delivered to the household as contributed by solar power supplied to operate the system and auxiliary power to maintain tank temperature at proper level, overall system efficiency and to determine temperature distribution within the tank. The tests and evaluation were performed at the Marshall Space Flight Center solar test facility.

The Solar Hot Water system is termed a "Dump-type" because of the draining system for freeze protection. The solar collector is a single glazed flat plate. An 82-gallon domestic water heater is provided as the energy storage vessel. Water is circulated through the collector and water heater by a 5. 3 GPM capacity pump, and control of the pump motor is achieved by a differential temperature controller.

For long range thermal performance tests on the LARGO Solar Hot Water System, see DOE/ NASA CR-150842.

$$
\text { DOE/ NASA CR-150842. }
$$

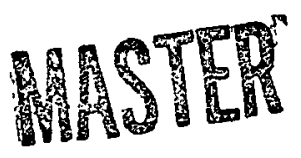

17. KEY WORDS

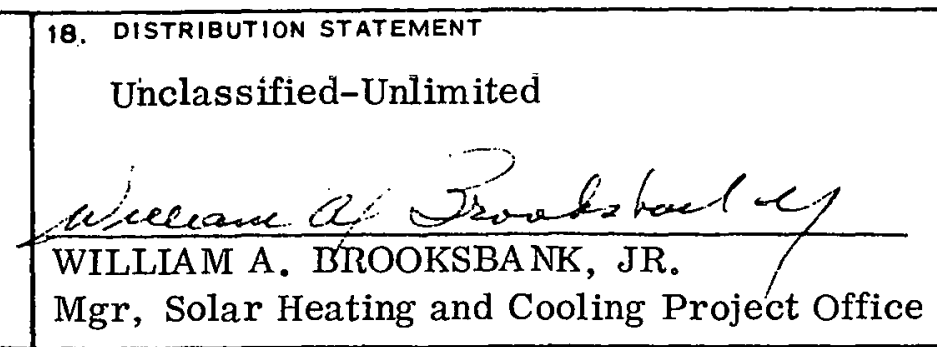

19. SECURITY CLASSIF, (of thle report)

Unclassified

20. SECURITY CLASSIF. (of this page)

Unclassified

34

NTIS 


\section{THIS PAGE \\ WAS INTENTIONALLY \\ LEFT BLANK}


TABLE OF CONTENTS

Page No.

1.0

2.0

3.0

4.0

5.0

6.0

7.0

8.0

TABLE I

TABLE II

Figure 1

Figure 2

Figure 3

Figure 4

Figure 5

Figure 6
SUMMARY

PURPOSE

REFERENCES

MANUF ACTURER

DESCRIPTION OF TEST SPECIMEN

TEST CONDITIONS AND TEST EQUIPMENT

6.1 Ambient Conditions

6.2 Instrumentation and. Equipment

TEST REQUIREMENTS AND PROCEDURES

7.1 System Operational Functional Test

7.2 System Operational Test

ANALYSIS

List of Measured Parameters

15

Summary of Thermal Performance Parameters

16

LARGO Solar Hot Water system

Installation Schematic

Sketch of IARGO system with

Instrumentation Locations

18

Sketch of Modified Piping on LARGO

System with Instrumentation Lcoations

Typical Temperature Stratification

Measurements During Overnight. Storage

20

Typical Temperature stratification Measurements During System Operation (October 13, 1977)

Plot of Measured Bulk Average Domestic Hot Water Temperature and Ambient Air Temperature Versus Time $(9 / 28 / 77)$

1

2

2

2

3

5

5

5

7

7

9

12 6 
TABLE OF CONTENTS (Continued)

Page No.

Photograph 1. LARGO Collector Mounted on Test Bed \# 1

Photograph 2. Installed Differential Pump Controller and Freeze Protection Controller

Photograph 3. Water Heater, Pump and Piping System

APPENDIX I LARGO SYSTEM MAGNETIC TAPE RECORD DESCRIPTIONS AND DATA ACQUISITION SYSTEM BLOCK DIAGRAMS

APPENDIX II * LARGO SYSTEMS TEST DATA

* Appendix II has been published as a separate volume in the Wyle Test Report, TR-531-19. 
Thermal performance tests of the LARGO Solar Residential Hot Water System were initiated on September 22, 1977. Results of initial tests revealed that the water flow rate thru the collector was restricted. This restriction was found to be due to a three-way solenoid valve which was located upstream of the sys tem pump. The system manufacturer was informed of the restricted flow condition. Subsequently, the three-way valve and associated piping was modified such that satisfactory flow rates could be achieved. Thermal performance tests were continued on September 28, 1977 thru October 14, 1977 wi thout other system related problems occuring. Additional tests are scheduled. This additional testing phase was scheduled for purposes of obtaining long-thermal performance data on the system.

A summary of performance parameters as determined from operational data on the first phase of testing is presented in Table II.

It is intended that this report will be updated upon completion of the second phase of testing. The final report will be issued as a consolidated document which will include results of both test phases. 
The purpose of this document is to present the results of tests of the LARGO Solar Hot Water System under natural environmental conditions.

Primary objectives of these performance evaluations are to:

- Determine the amount of energy collected by the system.

- Determine the amount of energy that is delivered to the household as contributed by solar.

- Determine power supplied to uperate the system and auxiliary power to maintain tank temperature at proper level.

- Determine overall system efficiency.

- Determine temperature distribution (stratification) within the tank.

The test program was conducted to determine the performance of the system to the evaluation requirements of Reference 3.1 in accordance with Reference 3.2

3.0 REFERENCES

3.1 NBSIR $76-1137$

3.2 Informal Statement of Work (Approved by MSFC)

3.3

3.4

3.5

4.0

Equipment

Collector
ASHRAE $93-77$

NBS TN899

MSFC MMI5300.4C

MANUFACTURER
Manufacturer
Thermal Data Requirements and Performance Evaluation Procedures for the National Solar Heating and Cooling Demonstration Program LARGO Solar Hot Water Heater Test Program.

Method of Testing Solar Collectors Based on Thermal Performance

Proposed Standards for Testing Solar Collectors and Thermal Storage Devices

Metrology and Calibration

Model No. $H R-410 S R$

LARGO Solar Systems, Inc. 2525 Key Largo Lane

Fort Lauderdale, Florida 33312

Residential Electric Water Heater

RHEEM Water Heater, Div.

7600 South Kedzie Avenue

Chicago, Illinois $: 60652$

$R P-82-2$ 
4.0 MANUFACTURER. (Continued)

Equipment

Water Pump

3-Way Water Valve

Controller

Solenoid Driver
Manufacturer

March Manufacturing Co., Inc.

11914 U.S.1

Juno, Florida 33408

Automatic Switch Co.

Florham Park, New Jersey 07932

Hawthorne Industries, Inc.

Solar Energy Division

1501 South Dixie

West Palm Beach, Florida 33401

Del-Sol Control Corp.

11914 U.S.1

Juno, Florida 33408
Model No.

809 HS

8320A85

H1503

OA2

\subsection{DESCRIPTION OF TEST SPECIMEN}

Presented in Figure 1 is a sketch of the LARGO Solar Systems, Inc. Solar Hot Water System which was tested. Major subsystem/components on the "Dump Type" system are designated in the sketch. The system is termed a "Dump Type" because of the draining system associated with freeze protection on the collector.

In the course of testing, it was found that the 3-way solenoid valve caused a large flow restriction down-s.tream of the pump. Modifications in the piping system and removal of the 3-way valve and bleed line were necessary to achieve satisfactory flow rates.

The modified piping system is shown in Figure 3, where the 3-way valve and the bleed line were replaced by copper tubing and a manual control valve.

The solar collector is a single glazed flate plate, with gross area of $40 \mathrm{Ft}^{2}$ and aperture area of $38.25 \mathrm{Ft}^{2}$. An 82 gallon domestic water heater is provided as the energy storage vessel which includes a conventional heater element with a maximum power rating of $3.0 \mathrm{~kW}$. Water is recirculated thru the collector and water heater by a 5.3 GPM capacity pump, and control of the pump motor is achieved by a differential temperature controller. Temperature sensors for the differential temperature controller are located at the collector fluid outlet and adjacent to the domestic water heater lower thermostat position.

A second differential temperature controller is employed on the system for purposes of freeze protection. The controller senses lemperature at the collector outlet manifold and controls the operation of a solenoid actuated valve to drain water from the system. An automatic air vent is located near the collector outlet to allow air to displace the water in the collector tubes and the piping system upon activation of the drain valve. 
5.0 DESCRIPTION OF TEST SPECIMEN (Continued)

Photographs 1 thru 3 show the system components installed on Test Bed \#1 at the Sol.ar Test Facility as located at Marshall Space Flight Center, Alabama. 
6.0 TEST CONDITIONS AND TEST EQUIPMENT

$6.1 \quad$ Ambient Conditions

Unless otherwise specified in the procedure, the testing will be conducted in natural ambient conditions.

6.2 Instrumentation and Equipment

All test equipment and instrumentation used in the performance of this test program comply with requirements of Réference 3.5 . All sensor output signals are monitored, recorded and processed by the data acquisition system located in Building 4646. A listing of the equipment specifications is provided as follows:

Apparatus/Function

Platinum Resistance Thermometer/

Collector Fluid Loop Temperature:

(1) Collector inlet

(1) Collector outlet

Platinum Resistance Thermometer/

(1) Water supply to tank

(1) Tank outlet to load

Flow Meter/

(1) Water flow rate thru collector

(1) Water flow rate to load

Electrical Power/

(1) Pump and control system

(1) Waler heater element

Pyranometer/Solar Flux Transducer

Wind Velocity Sensor

Wind Direction Sensor

(6) Thermocouples*/

water temperature profile in tank

(6) Platinum Resistance Thermometers $* *$ / water temperature profile in domestic water heater tank
Manufacturer/Model Range/Accuracy

$\mathrm{Hy}$-Cal Engineering/

$4135-A$

$50-250^{\circ} \mathrm{F} \pm .9^{\circ} \mathrm{F}$

$50-250^{\circ} \mathrm{F} \pm .9^{\circ} \mathrm{F}$

Hy-Cal Engineering/

4135-A

$40-100^{\circ} \mathrm{F} \pm .9^{\circ} \mathrm{F}$

$50-250^{\circ} \mathrm{F} \pm .9^{\circ} \mathrm{F}$

Foxboro/

$1 / 2-2-8173 C 1$

.23 to 2 GPM $\pm 1 \%$ FS

Potter Meter Co./

1/2-270

$0-9$ GPM $\pm 1 \%$ FS

Ohio Semitronics/

PC5-10

Ohin Semi tronics/

PC5-29

$1.2 \mathrm{KW} \pm 5 \% \mathrm{FS}$

$0-12 \mathrm{KW} \pm .5 \% \mathrm{FS}$

Eppley/PSP

Teledyne Geotech/ M1567

Teledyne Geotech/

$0-400 \mathrm{BTU} / \mathrm{Hr} \cdot \mathrm{Ft}^{2} / \pm 3 \%$

Omega/Type T

$.75-65 \mathrm{MPH} / \pm .5 \%$

$\mathrm{Hy}-\mathrm{Ca}$ Engineering/

4125-A

*(6) Thermocouples measurements to be recorded on strip chart recorder, separately. ** This instrumentation was used in the second phase of LARGO system tests. 
6.0 TEST CONDITIONS AND TEST EQUIPMENT (Continued)

6.2.1 Instrumentation Designation

The location of instrumentation on the LARGO, Inc. Solar Water Heater System is indicated in Figure 2. A detailed instrumentation list is provided in the Instrumentation and Component list (IP\&CL Revision A-15). Instrumentation block diagrams depicting the primary data acquisition set up utilized during these tests are shown in Appendix I. Descriptions of the magnetic tape records from LARGO system operational tests are also provided in Appendix I.

Al1 transducers with the exception of the Eppley PSP pyranometer used in recording test data are calibrated by either NASA or AMC calibration laboratories as required by MSFC MMI 5300.4C. The PSP pyranometer is calibrated by Eppley.

The end-to-end accuracy of data derived from system testing is subject to an error analys is which accounts for all inaccuracies in the transducer, signal conditioning, signal transmission and computer processing methods. Since a formal systems error analys is will not be done, confidence in printout accuracies were established by installing calibrated "parallel" transducers and direct readouts at key points in the system and performing comparison checks from time to time before, during, and after tests. The results of such checks together with a review of the data for anomalies indicates that the data presented is suitable for the purpose intended. 
Tested by

Started

Completed

7.1.1 Performance Criteria Requirements

Functional tests shall be conducted on the LARGO Solar Hot Water System to determine that major components of the system operate properly after installation on Test Bed No. 1. The system operational functional test shall consist of the following individual tests:

- A system pressure/leakage test.

- An operation test on the freeze protection system.

- An operational test of the system pump/controller.

7.1.2 Test Procedure

1. Install the LARGO Solar Hot Water System on Test Bed No. 1. The system installation is illustrated in Figure 1.

2. Connect the potable water supply to domestic water heater cold water inlet and fill the system. Activate pump and circulate water thru the collector and return to the domestic water heater. Monitor the water flow rate thru the system to assure that the pump is functioning properly (water flow rates of 1 to 5 GPM), then deactivate the pump.

3. Check the system for leaks. If leaks are found, repair them and recheck the system.

4. Activate freeze protection system by application of ice on the freeze protection sensor. The solenoid driver should operate the 3-way valve to drain the system. Allow the freeze sensor to return to a temperature greater than approximately $40^{\circ} \mathrm{F}$. The 3-way valve should operate to refill the collector.

5. To check the differential temperature controller, apply power to the controller and monitor pump operation (1 to $5 \mathrm{GPM}$ flow rate is normal). Apply power to the water heater element and monitor water temperature response in the tank. As the water temperature stabilizes, the differential temperature controller should operate to deactivate the pump. The pump controller check out procedure to deactivate the pump may require that the collector aperture be shaded for conditions of high solar insolation. 
7.0 TEST REQUIREMENTS AND PROCEDURES (Continued

7.1.3 Results of Functional Tests

1. The pump was determined to be functioning properly. However, the flow rate thru the collector circuit was restricted to approximately $0.3 \mathrm{GPM}$.

2. No leaks were discovered during systems leak tests.

3. The freeze protection sensor/controller did not actuate the 3-way solenoid valve to the normally open condition for circulation of water thru the collector loop. Operation of the system was achieved manually by removing power from the solenoid driver. The freeze protection sensor/controller did not function to operate the 3-way solenoid actuated valve when the sensor was subjected to temperature of $32^{\circ} \mathrm{F}$. Also, it was noted that the freeze protection system, would not prevent freezing under conditions of electrical power failure. 
$7.2 \quad$ System Operational Test.

7.2.1 Performance Criteria Requirements

The LARGO Solar Hot Water System shall be tested to experimentally determine the system's operational thermal and performance characteristics. Measurements and data shall be accumulated over an operational period of approximately two weeks (assuming predominately sunny weather) under natural climatic conditions. These tests shall be conducted at the Test Bed No. I Facility using a simulated hot water load schedule. Complete weather records will be maintained including total solar radiation incident normal to the collector plane, ambient temperature, wind speed and direction.

Data shall be recorded during system's operation as necessary to evaluate the following performance parameters on a daily basis.

- Total energy collected by the solar system.

- Total energy supplied to operate the system and the auxiliary energy consumed by the domestic water heater.

- Total energy supplied to hot water load as contributed by solar system.

- Overall system efficiency.

- Temperature stratification profile in domestic water heater.

7.2.2 Test Procedure

1. Turn on city water supply to domestic water heater. Apply power to freeze protection controller, pump controller and the domestic water heater. Operate the system for 24 hours under a no-load condition.

2. Tests performed subsequently, shall require that the system be operated during the normal work schedule, Monday through Friday. The system shall be operated continuously under a simulated load condition from 8:00 a.m. until 4:00 p.m.

3. The daily operational hot water loading sequence is as follows:

Time

$0745 \mathrm{Hrs} \pm 15 \mathrm{Min}$

$0800 \mathrm{Hrs} \pm 15 \mathrm{Min}$

$1200 \mathrm{Hrs} \pm 15 \mathrm{Min}$

$1700 \mathrm{Hrs} \pm 15 \mathrm{Min}$

\section{Operation}

Apply power to system

Drain $21 \mathrm{Gal} . \pm .5 \mathrm{Gal}$.

Drain $21 \mathrm{Gal}$. 5 Gal.

Drain $21 \mathrm{Gal} . \pm .5 \mathrm{Gal}$. 
7.2.2 Test Procedure (Continued)

The water will be drained from the domestic water heater at the rate of 3 GPM \pm 0.2 GPM into a graduated container. The container will be accurately marked to indicate from 0 to 35 gallons with subdivisions of $1 / 2$ gallons.

4. Monitor system operation and check for malfunctions or leaks thru the test duration. This operation will be performed at the intervals specified in Procedure 3, above.

5. Throughout the test interval, data will be accumulated on the data system located in Building 4646.

\subsubsection{Results of Operational Tests}

A list of measured quantities and corresponding parameters which were presented in graphical form is provided in Table I. All test data as recorded on magnetic tape during operational testing were processed after completion of tests and subsequently computer plots were prepared.

System operational performance parameters were evaluated on a daily basis and are summarized as shown in Table II. The methods used in the evaluations are outlined in Paragraph 7.0 of the report.

In the first test phase, temperature stratification measurements were recorded on a strip chart. These measurements were used to prepare graphs to show the temperature profile of the water during the system operation. Grophs of measured temperature profiles in the domestic water heater tank are also presented in Appendix II. Temperature stratification effects which were observed during the tests are delineated below:

- During periods when the system pump is inactive, the axial temperature distribution in the tank shows significant stratification effects. Typical measured transient temperature stratification effects are shown graphically in Figure 4. The upper and lower temperature sensors were plotted as a function of time during overnight storage with the upper tank thermostat and electrical heater element active.

- Typical temperature stratification effects during the proximity of time at which the hot water load occured are shown in Figure 5 
7.0 TEST REQUIREMENTS AND PROCEDURES (Continued)

7.2.3 Results of Operational Tests (Continued)

It is apparent from this graph that a limited amount of mixing existed in the tank during the time that city water was admitted at the tank bottom and hot water was discharaed from the top.

- Circulation of fluid thru the tank by the system pump results in mixing which relaxes the stratification effects which existed prior to activation of the pump. This effect is indicated in Figure 5, where the transient upper and lower tank temperature measurements are plotted.

Test data was recorded over a 24 hour basis to evaluate the overall heat transfer loss coefficient ( $U_{L}$ ) of the domestic water heater. This test data consisted of bulk average temperature of water in the tank and the ambient air temperature which are shown graphically in Figure 6 as functions of time. The overall tank heat transfer coefficient was determined to be 9.6 BTU $/ \mathrm{Hr}^{\circ} \mathrm{F}$. 
Analyses were performed of data obtained from LARGO system tests to evaluate thermal performarice parameters. Equations used to evaluate the test data are indicated in the following paragraphs.

Solar Energy Available

The total daily solar energy available was calculated for the interval of time that the LARGO system controller and simul-. taneously the data acquisition system were active.

where,

$$
Q_{s}=\int_{\tau_{1}}^{\tau_{2}} 1001 A_{C} d \tau
$$

$Q_{S}=$ Total daily solar energy available

$A_{c}=$ Gross collector area

I001 = Measured solar insolation

$\tau=$ Time

\section{Solar Energy Collected}

The quantity of solar energy collected on a daily basis was evaluated by,

where,

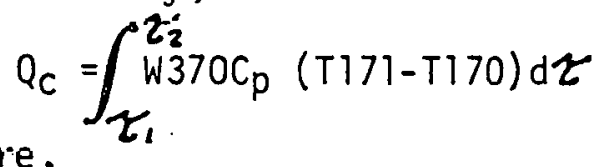

$Q_{c}=$ Solar energy collected

$W 370=$ Liquid. flow rate

$c_{p}=$ Specific heat

TI7l = Collector fluid outlet temperature

T170 = Collector fluid inlet temperature

$\tau=$ Time

Hot Water Load

The total dally hot water loads "were evaluated using the equation, where,

$$
Q_{H}=C_{p} \sum_{n=0}^{n} M_{n}(T 372-T 371)_{n}
$$

$$
Q_{H}=\text { Total daily hot water load }
$$


$C_{p}=$ Specific heat

$M=$ Mass of water during each load

$($ T372-T371) = Temperature difference between outlet to load and city water inlet during each load interval

\section{Total Electrical Energy}

The total electrical energy was the sum used by the hot water heater element and the pump.

$$
Q_{E}=\int_{\tau_{1}}^{\tau_{2}} E P 370 d \tau+\int_{\tau_{1}}^{\tau_{2}} E P 371 d \tau
$$

where,

$$
\begin{aligned}
& Q_{E}=\text { Total electrical energy used } \\
& E P 370=\text { Electrical power of heater element } \\
& E P 371=\text { Electrical power of pump } \\
& \tau=\text { Time }
\end{aligned}
$$

Overall Heat Transfer Loss Coefficient of Hot Water Tank

This parameter was evaluated by the recording of liquid temperature existing in the tank and the ambient air temperature over night on a strip chart. Temperature sensors used to establish liquid temperature profiles were used to determine a bulk average temperature transient and the overall loss coefficient was evaluated by,

$$
U_{L}=\frac{V_{t} P C p(\overline{\bar{T}} i-\bar{T} f)}{\Delta \tau(\bar{T} w-\bar{T} a)}
$$

where,

$$
\begin{aligned}
& U_{L}=\text { Overall tank heat transfer coefficient } \\
& V_{t}=\text { Volume of tank } \\
& P=\text { Density } \\
& C_{p}=\text { Specific heat } \\
& T_{i}=\text { Initial liquid bulk average temperature } \\
& \bar{T}_{f}=\text { Final liquid bulk average temperature } \\
& \Delta \tau=\text { Time interval from initial to final conditions }
\end{aligned}
$$


8.0 ANALYSIS (Continued)

$\begin{aligned} \bar{T}_{W}= & \text { Arithmetic average temperature of bulk liquid for } \\ \text { time interval } & \end{aligned}$

$\overline{\mathrm{T}} \mathrm{a}=$ Arithmetic average ambient air temperature for time interval 


\section{TABLE I}

List of Measured Parameters

\section{Measurement}

Solar radiation

Ambient temperature

Wind speed/direction

Collector inlet temperature

Collector outlet temperature

City water supply temperature

Hot water system outlet temperature (to load)

System temporary shelter temperature

Hot water flow rate to load

Water flow rate thru collector

System pump power

Domestic hot water heating element power Temperature stratification profile in domestic hot water tank

\section{Parameter}

$\mathrm{BTU} / \mathrm{Hr} / \mathrm{Ft}^{2}$ vs. time of day

${ }^{\circ} \mathrm{F}$ vs. time of dav

$\mathrm{MPH} /$ direction $\mathrm{Vs}$. time of day

${ }^{\circ} \mathrm{F}$ vs. time of day in hours

${ }^{\circ} \mathrm{F}$ vs. time of day in hours

${ }^{\circ} \mathrm{F}$ vs. time of day in hours

${ }^{\circ} \mathrm{F}$ vs. time of day in hours

${ }^{\circ} \mathrm{F}$ vs. time of day in hours

GPM vs. time of day in hours

GPM vs. time of day in hours

Watts vs. time of dav in hours

Watts vs. time of day in hours

${ }^{\circ} \mathrm{F}$ vs. position in tank 
TABLE II

Summary of Thermal Performance Parameters

\begin{tabular}{|c|c|c|c|c|c|}
\hline $\begin{array}{l}\text { Performance } \\
\text { Parameter } \\
\text { Test Date, } 1977\end{array}$ & $\begin{array}{l}\text { Total Solar } \\
\text { Energy } \\
\text { Available, } \\
\text { BTU }\end{array}$ & $\begin{array}{l}\text { Total Energy } \\
\text { Collected, } \\
\text { BTU }\end{array}$ & $\begin{array}{l}\text { Total Electrical } \\
\text { Energy Used, } \\
\text { BTU }\end{array}$ & $\begin{array}{l}\text { Total Energy Supplied } \\
\text { To Hot Water Load } \\
\text { As Contributed } \\
\text { By Solar, BTU }\end{array}$ & $\begin{array}{l}\text { Overall } \\
\text { System } \\
\text { Efficiency, } \\
\%\end{array}$ \\
\hline $9-22$ & 78431 & 35380 & 1920 & 30267 & 39 \\
\hline $9-23$ & 64075 & 29780 & 1843 & 18650 & 29 \\
\hline $10-3$ & 82518 & $39: 150$ & 5344 & 36842 & 45 \\
\hline $10-4$ & 78962 & 35950 & 1686 & 37806 & -48 \\
\hline $10-6$ & 41170 & 10950 & 1703 & 10559 & 26 \\
\hline $10-7$ & 6.3775 & 24000 & 1605 & 25384 & $\therefore 40$ \\
\hline $10-14$ & 79901 & 36450 & 1755 & 34697 & 43 \\
\hline
\end{tabular}




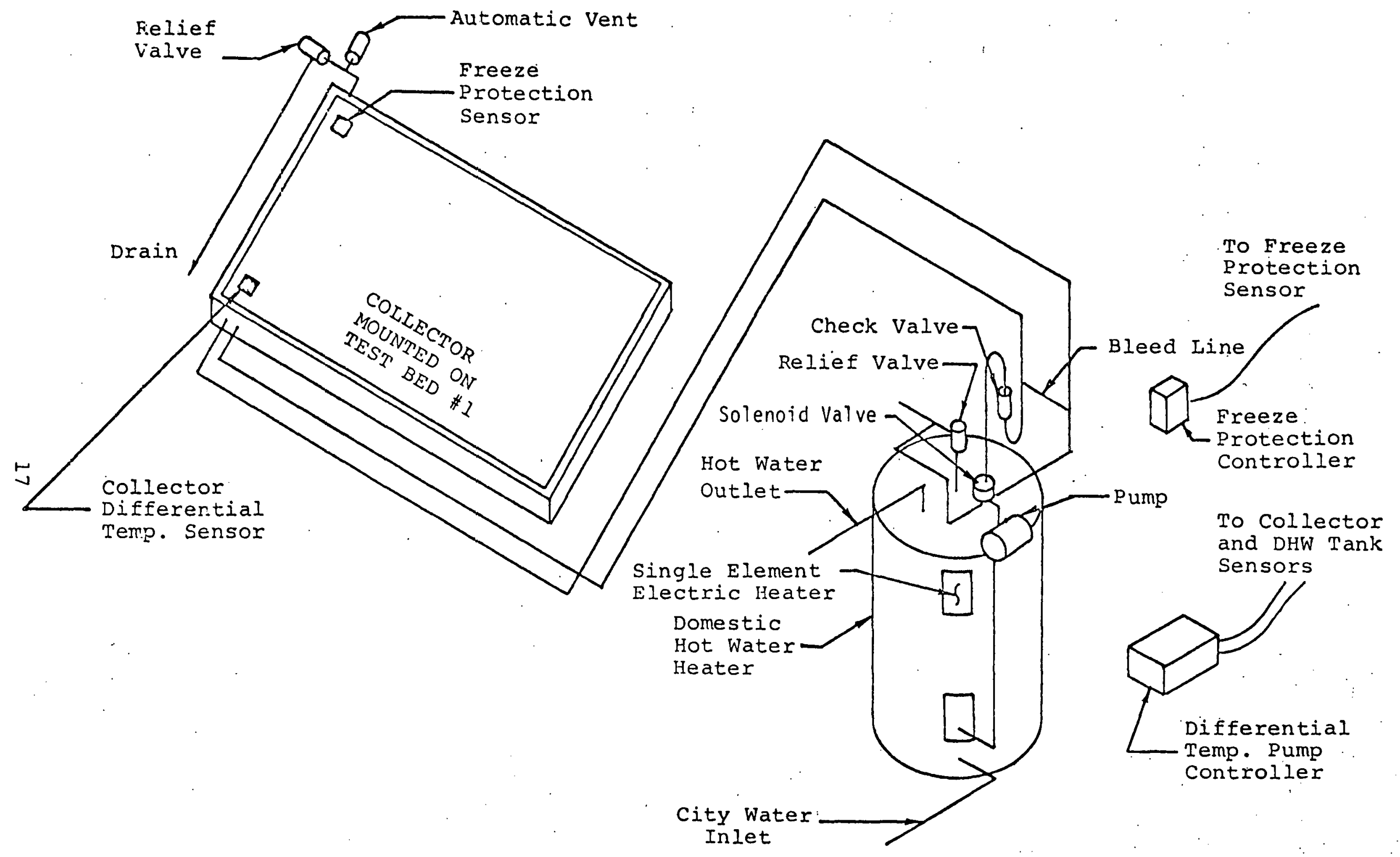

Figure 1. LARGO Solar Hot Water System Installation Schematic 


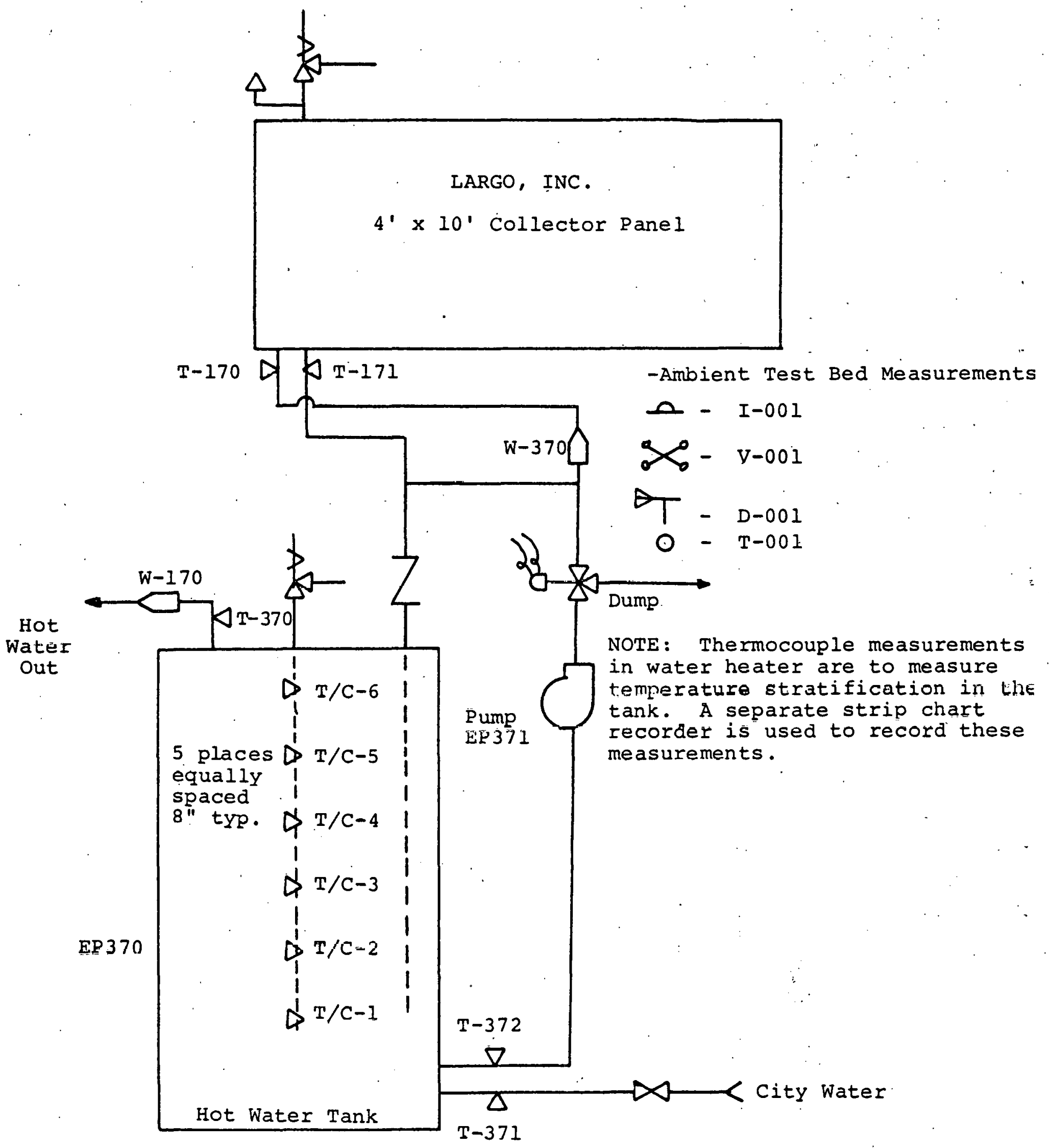

Figure 2. Sketch of LARGO System with Instrumentation Locations. 


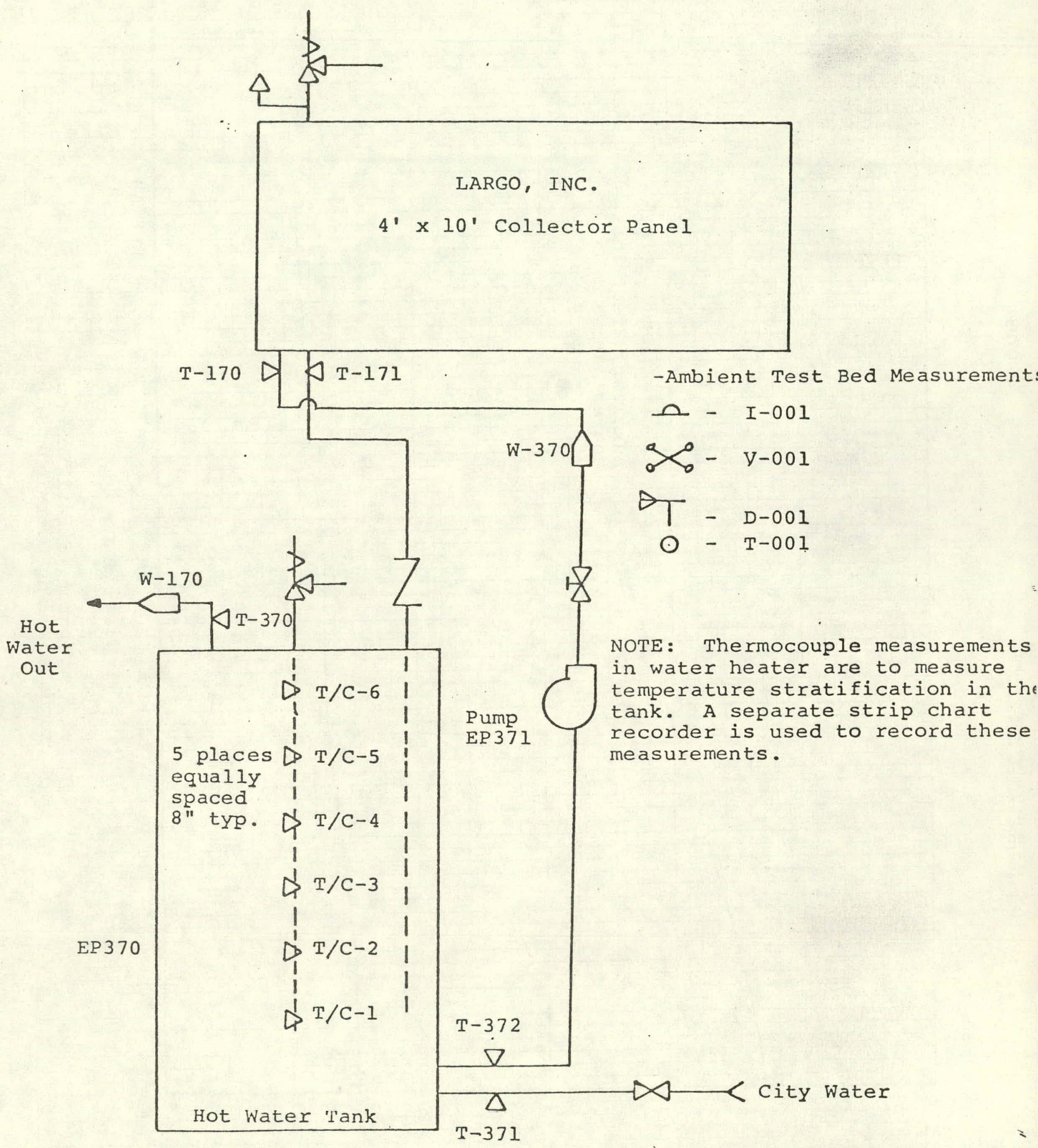

Figure 3. Sketch of Modified Piping on LARGO System with Instrumentation Locations 


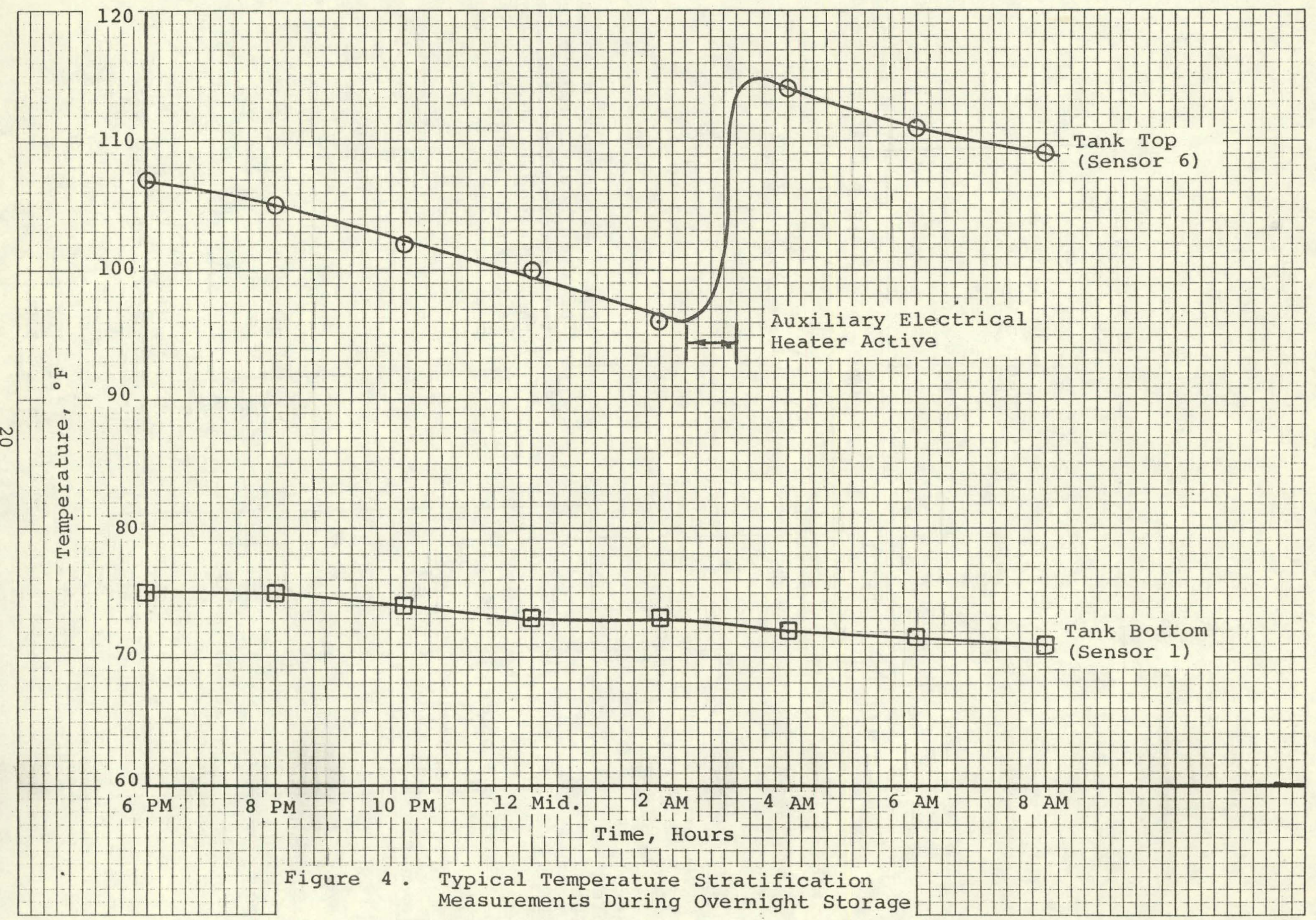




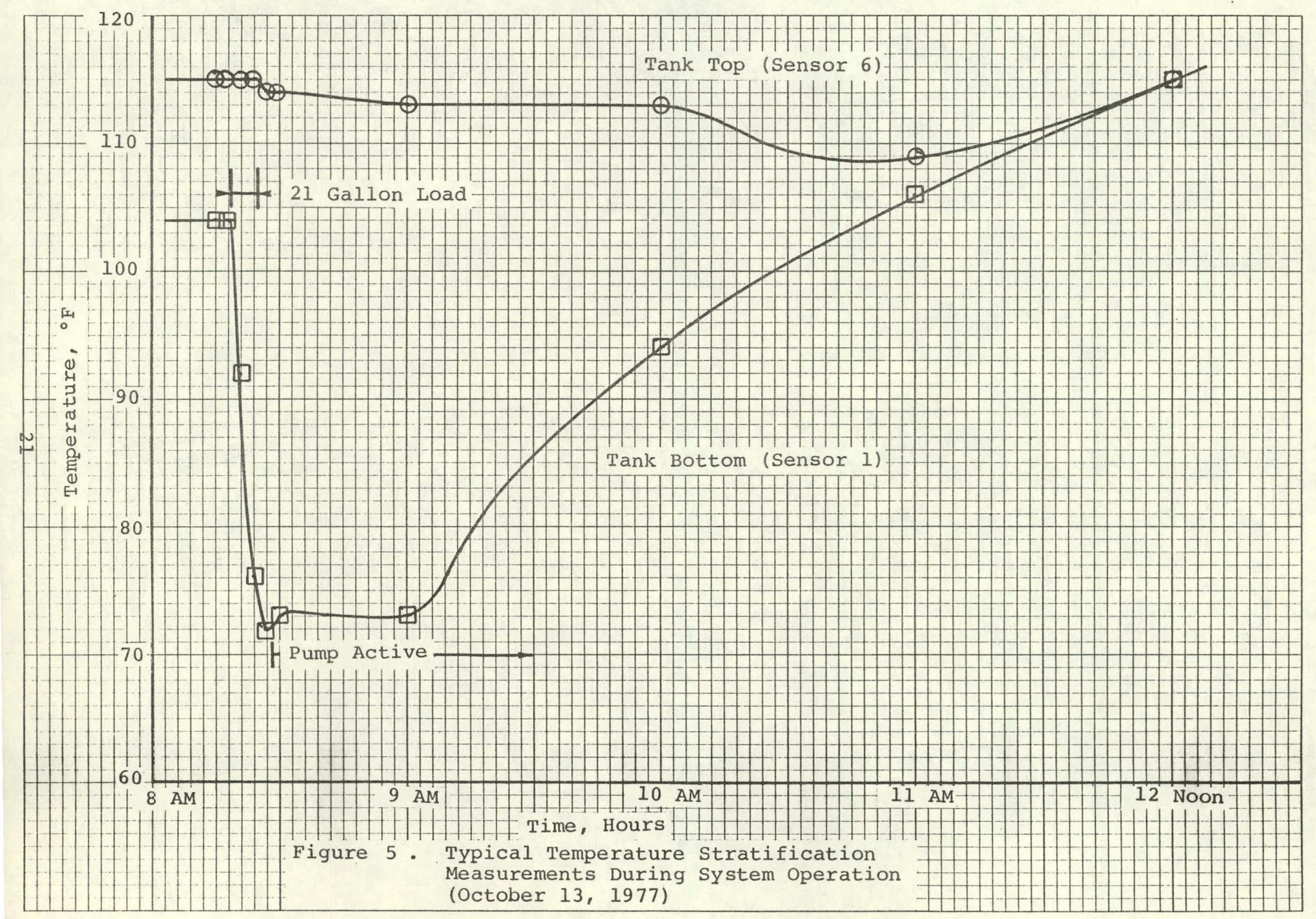




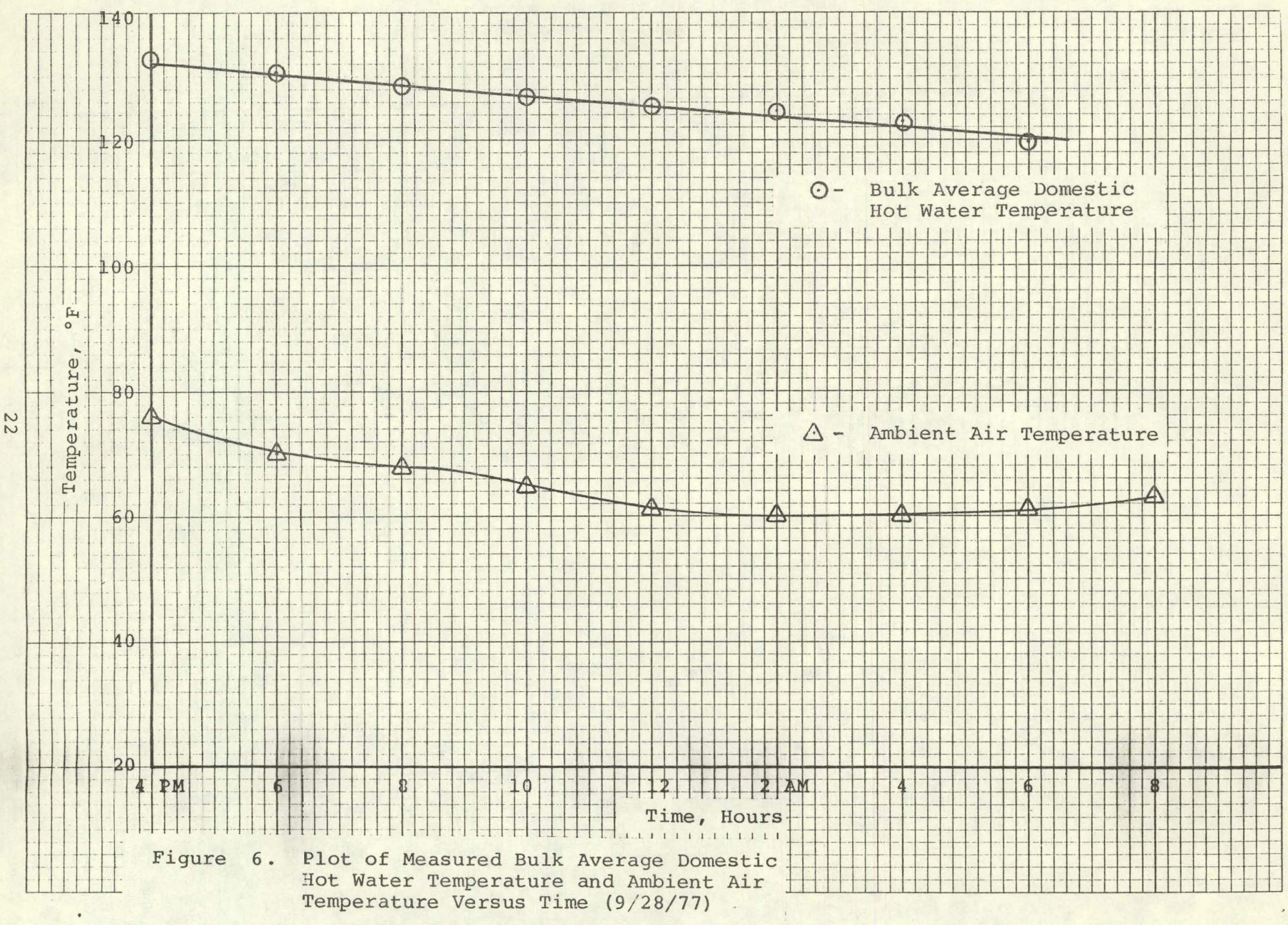




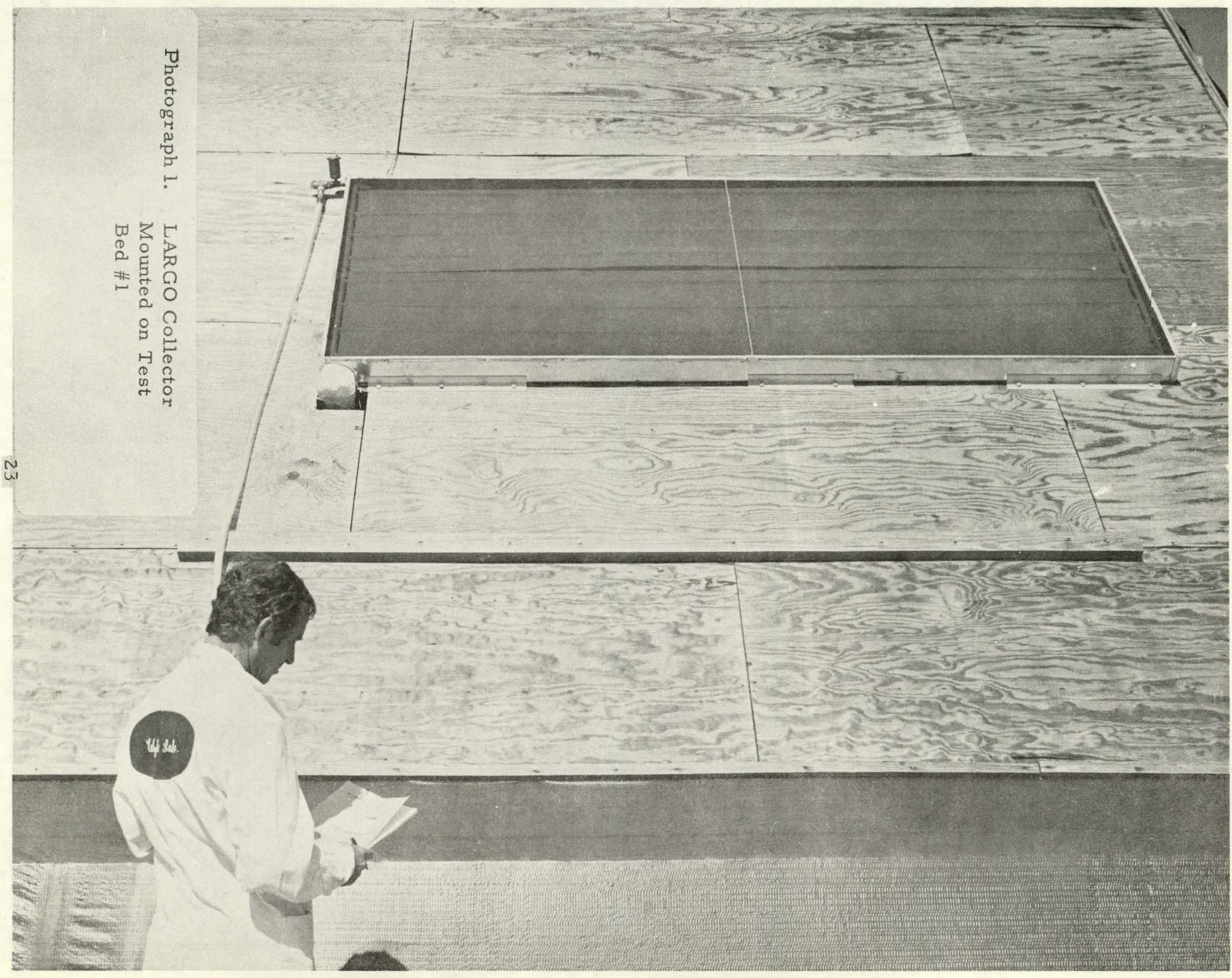




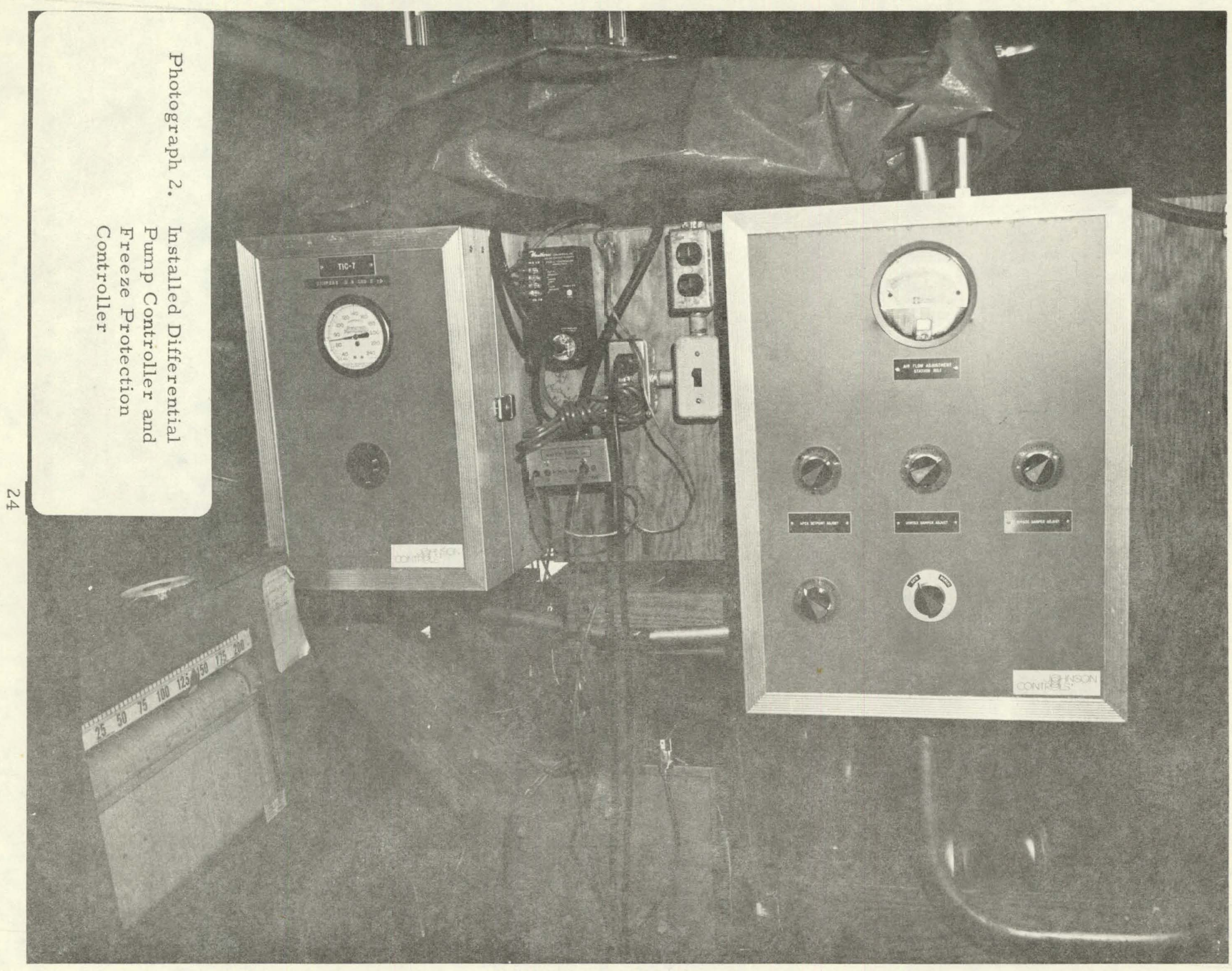




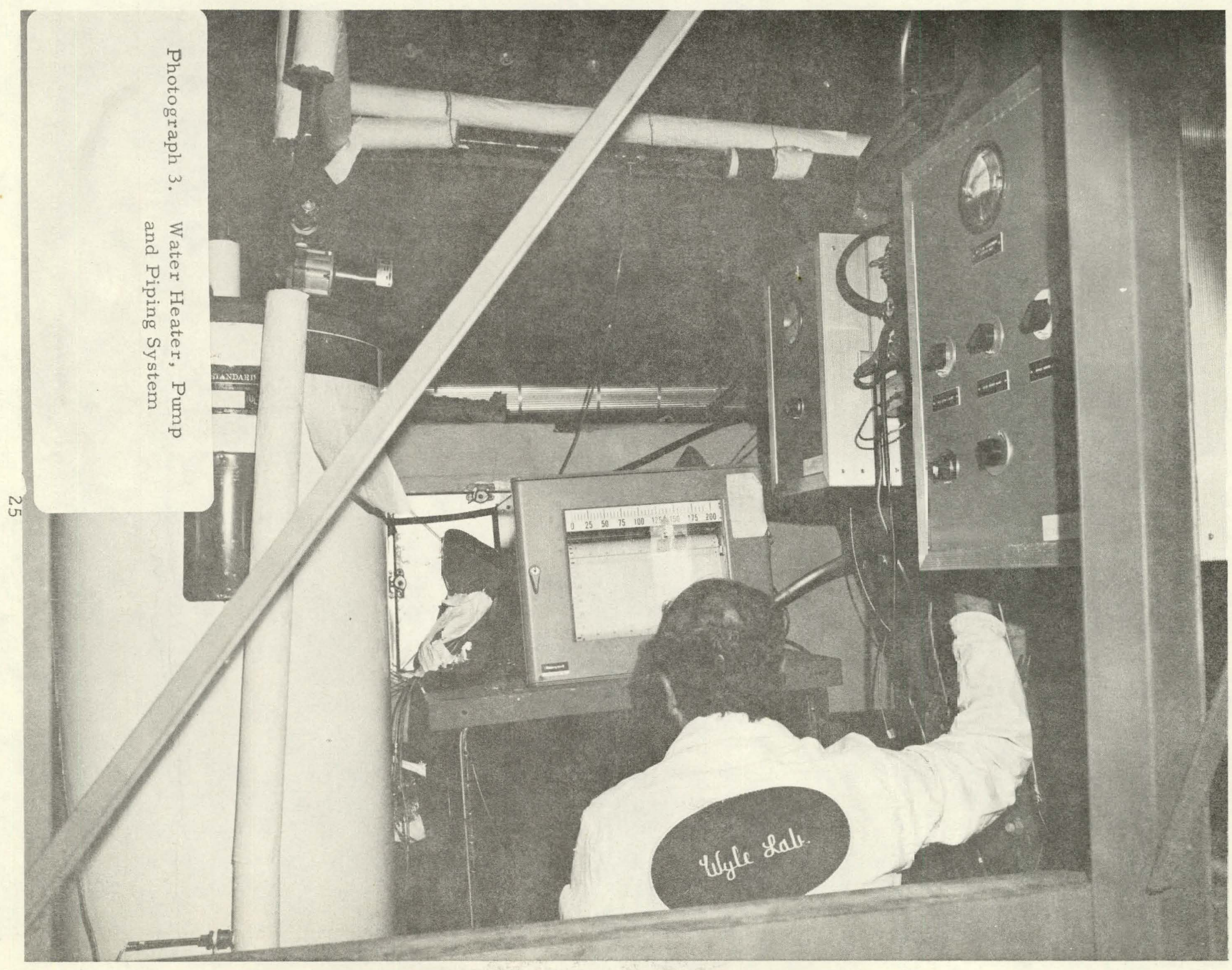


APPENDIX I

LARGO SYSTEM MAGNETIC TAPE

RECORD DESCRIPTIONS

AND

DATA ACQUISITION SYSTEM BLOCK DIAGRAMS 
Magnetic Tape Description

Computer magnetic tapes of data recorded in LARGo system tests will be supplied to IBM in addition to the information contained in Appendix II. A description of the DDP224 computer log tapes is provided below:

1. 7 tracks, 556 BPI and odd parity.

2. Each file in the tape contains one day of test data. The test data are in 1201-word records for succeeding daily tests.

3. The DDP-224 computer is a 24-bit word machine. Sets of two test data are packed into one word. The first ten bits contain the raw count of the first test data, bits 13 through 22 contain the raw count of the second test data. The first of each 1201 words gives the validity and record count. The remaining 1200 words contain 2400 test data in the order of ascending number.

4. Table I-A depicts the pulse code modulation ( $\mathrm{pcm}$ ) number, the coefficient for 4 th order engineering unitraw count conversion and the title of each sensor used for $M / N$ lB system test.

Block Diagrams of Data Acquisition Setup

Block diagrams of the data acquisition setup are depicted in Figure I-A. 
TABLE I-A

IISTING OF INFORMATION

NECESSARY TO CONVERT MAGNETIC TAPE DATA

TO ENGINEERING UNITS

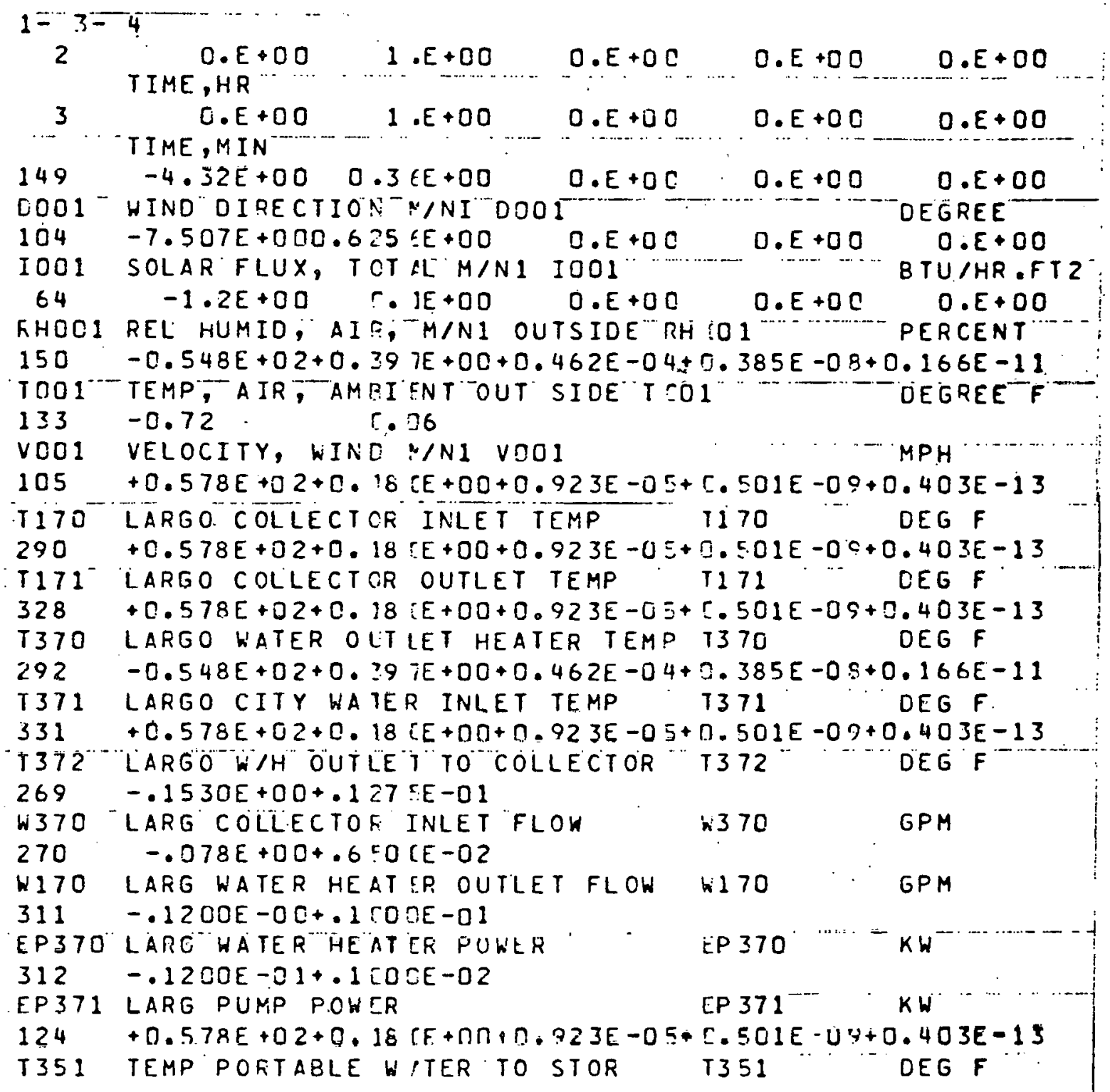




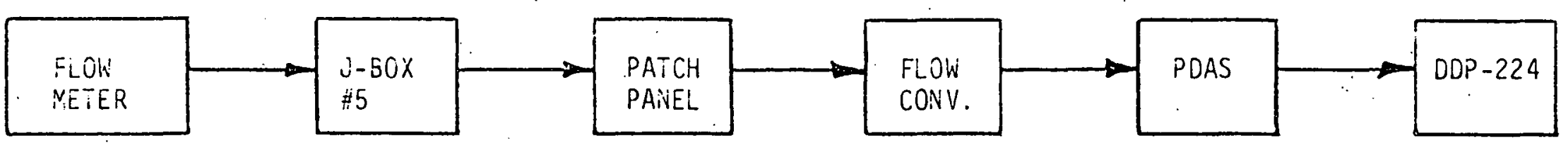

(2) Sensors

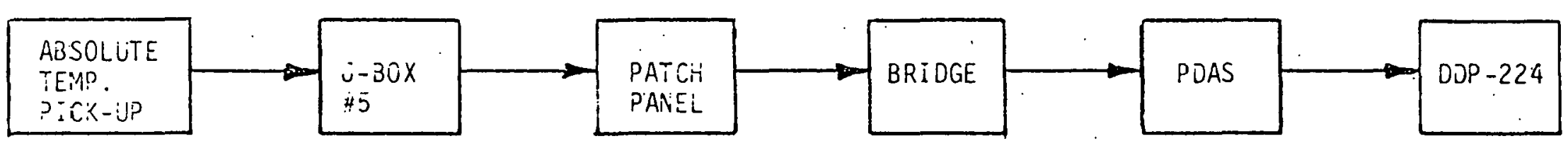

(5) Sensors

ก

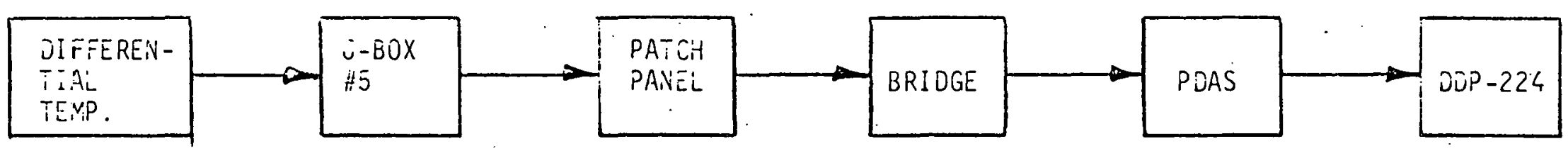

(0) Sensors

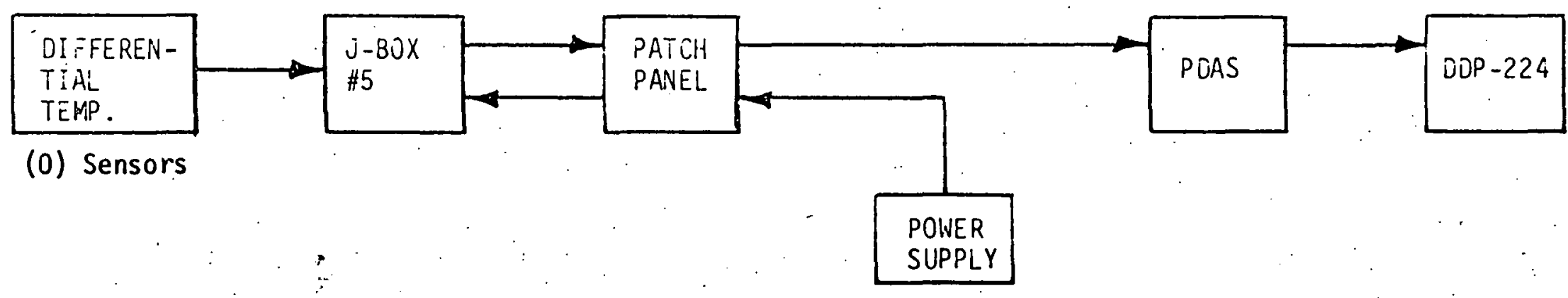

Figure 1-A. Block Diagram of Primary Data Acquisition system for LARGO System Test 


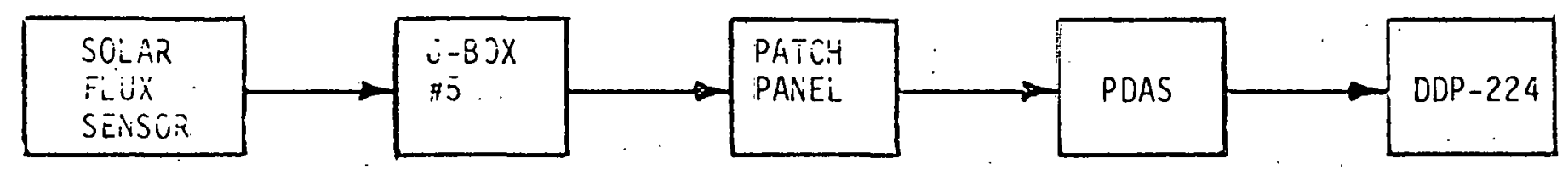

(1) Sensor

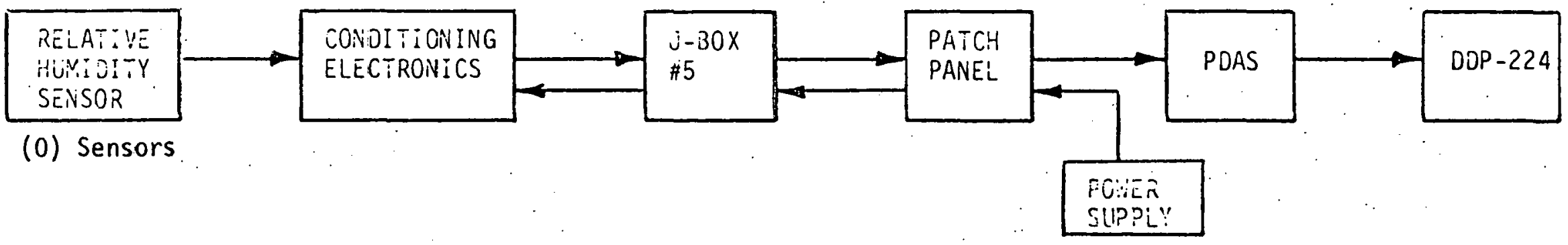

$\stackrel{w}{\circ}$

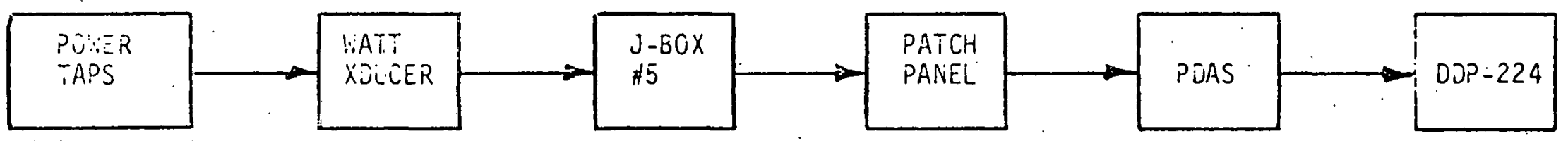

(2) Sensors

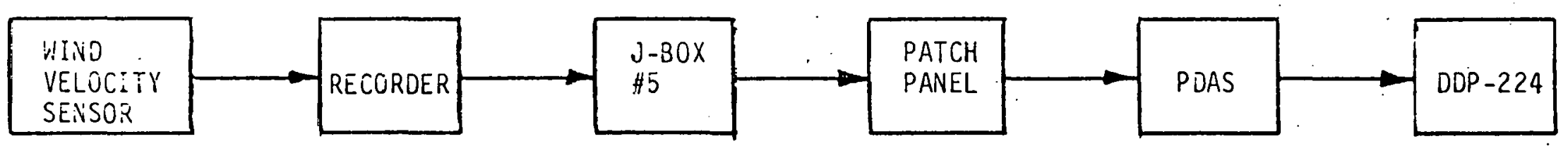

(1) Sensor

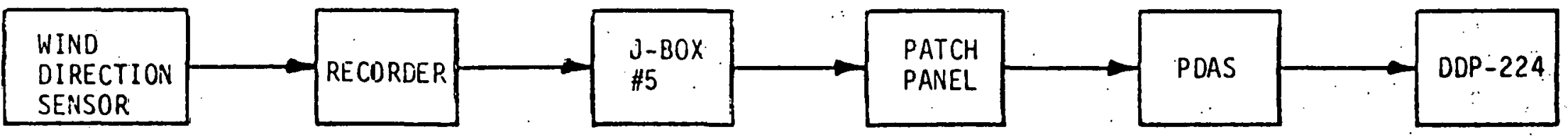

(1) Sensor

Figure 1-A (Continued) 

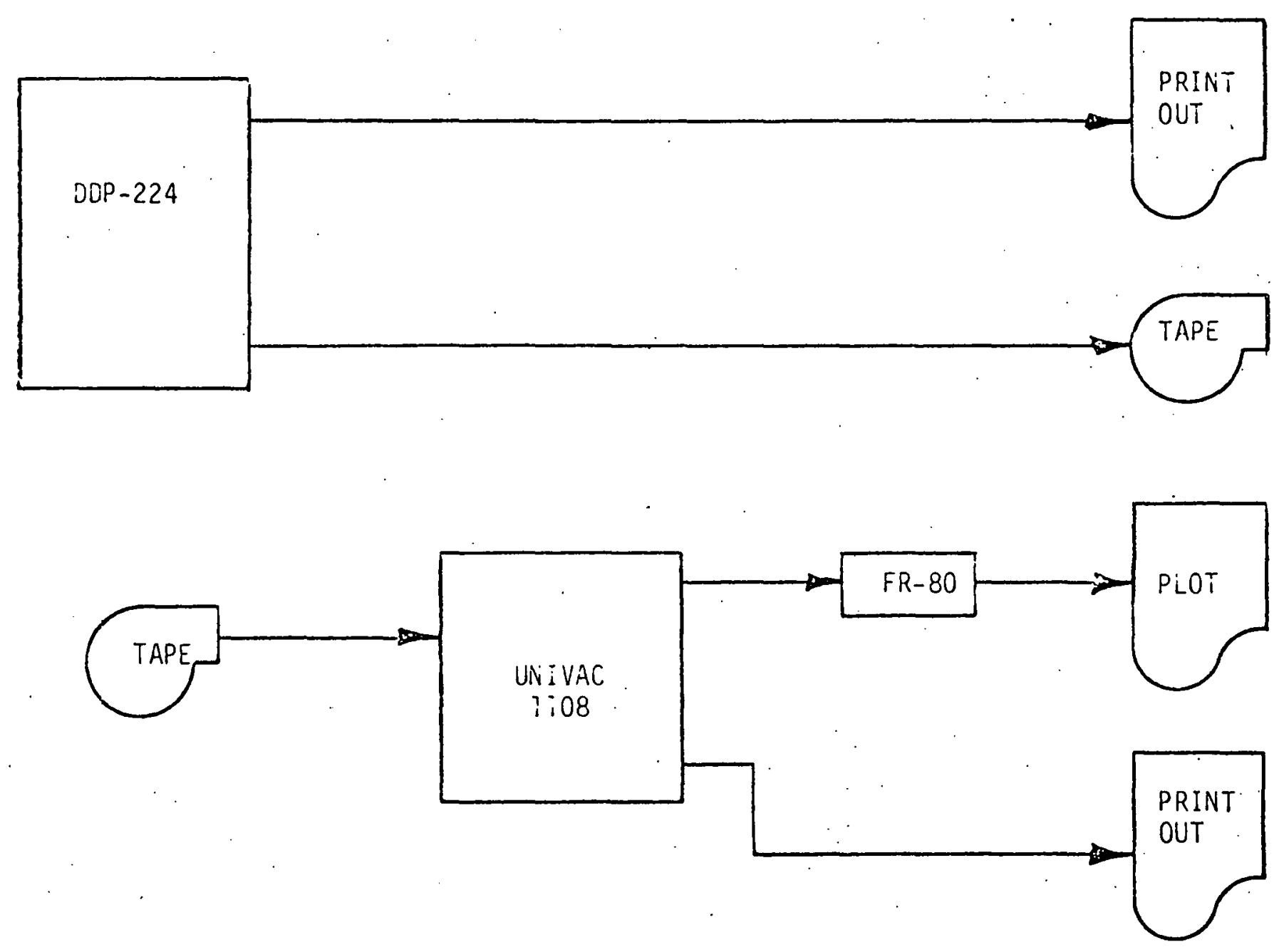

Figure 1-A (Continued) 